\title{
Problematics of Single Mother in Parenting
}

\author{
Malida Fatimah \\ Faculty of Psychology \\ University of Mercu Buana Yogyakarta \\ Yogyakarta, Indonesia
}

\author{
Junanah \\ Faculty of Islamic Studies \\ Islamic University of Indonesia \\ Yogyakarta, Indonesia \\ junanah@uii.ac.id
}

\begin{abstract}
The purpose of this study is to identify coping strategy, religious coping, and cognitive distortion among single mothers. The samples of this study were a hundred respondents that selected from the communities of single mothers in Yogyakarta. Data collected with a set of questionnaires that consists of three inventories. The reliability values of Cronbach Alpha for the inventories were in the range of .84 to .98 . Independent t-test, ANOVA and Pearson Correlation were used for data analysis. The study was found that the coping strategy of single mothers is cognitive restructuring with adaptive and maladaptive function as the second scale; the cognitive distortion is preoccupation of danger; and the religious coping is religious forgiving. The further results found that there was a significant relationship between coping strategy and cognitive distortion, while there was no significant relationship between religious coping and cognitive distortion. Based on the findings, several implications and recommendations were discussed.
\end{abstract}

Keywords- Single Mother, Coping Strategy, Cognitive Distortion, Religious Coping, Parenting

\section{INTRODUCTION}

Tulzak and Hillock (1988) and Olson and Haynes (1993) voiced that the general conceptions of the parenting hold requires the presence of both a mother and a father as a prerequisite for the child's satisfactory and adequate development. Such conceptions, which are confirmed and assigned to the realm of developmental psychology, have informed much in the research on single-parent families. Regarding the deficit model, a single-parent family is conceptualized as incomplete and deviant; single-motherhood is seen as a problem in itself (Naidoo, 1998).

The existence of a problem is a mandatory occurrence in human life, as well as in domestic life. Marriage is not just a union of two people, but also the merging of two large families, two cultures, two norms, two values of life, and the previous two different views. To undergo domestic life is not as easy as one might imagine; there will be problems over time in the marriage. The problems require couples to be able to take a thoughtful and mature attitude to save the integrity of the household. Maturity and communication between partners are needed to sustain a marriage. However, the fact of the matter is that loving one another has proven to be difficult for human beings throughout the millennia. Family problems are extraordinarily common in the American society and other countries around the world today. If it were all so very simple, people would have figured out how to live together happily a long time ago, and our lives would be perfect (DeFrain, 1999).
The changing patterns of marriage and divorce could be described as such: There has been an increasing number of female-headed nuclear families; and the reason of singlemotherhood has changed since "father absence" due to death or divorce or separation (Naidoo, 1998).

\section{A. Coping Strategy}

Lazarus and Folkman (1984) defined coping as a constantly changing cognitive and behavioral effort to manage specific external and internal demands that were appraised as taxing or exceeding the resources of the person. Sarafino (2008) retold from Lazarus and Folkman that coping is a process of an individual to manage the distance between demands and resources while feeling stress. Coping is the way to do some correction or dominate the problem. Coping also helps the individual to change their perception towards incorrect views, to tolerate or accept the threat or danger, escape, or to avoid the situation (Pitasari \& Cahyono, 2014)

Lazarus (1993) who developed the coping strategy approach, explained the Principles of the Process Approach in the Journal of Psychosomatic Medicine in 1993, such as adaptive and maladaptive, problem focused and emotion focused. First, Garcia, Franco, and Martinez (2007) concluded that focusing on adaptive and maladaptive includes problem solving, problem avoidance, and self-criticism. Problem solving is a cognitive and behavioral strategy aimed at eliminating stress by modifying the situation that produces it; problem avoidance is a strategy that includes rejection and avoidance of thoughts or acts related with stressful events; and self-criticism is a strategy based on self-blame and selfcriticism due to the occurrence of stressful situations or inadequate management.

Second, the theory of coping as a process emphasizes that there are at least two major/un-actions/coping; problemfocused and emotion-focused. The distinction is subscribed to widely by coping researchers. The function of problemfocused coping is to change the troubled person-environment relationship by acting on the environment or oneself (Lazarus, 1993). Problem focused coping is an approach that intends to decrease stressors or increase resources (Pitasari \& Cahyono, 2014). Taylor's (1995) perception towards Lazarus and Folkman, defined problem focused coping as the behavior of coping that focuses on the problem, how to solve the problem or doing something to decrease the stressor, used to diminish problems or stress felt by searching for the direct solution (Ariati \& Wahyuningsih, 2008). The function of emotionfocused coping is to change either a) the way the stressful relationship with the environment is attended to (as in vigilance or avoidance) or b) the relational meaning of what is 
happening, which mitigates the stress even though the actual conditions of the relationship have not changed. The latter involves a more benign or less threatening reappraisal, as illustrated, for example, in denial and distancing (Lazarus, 1993). Emotional focused coping intends to control emotional responses trough the stressful situation (Pitasari \& Cahyono, 2014).

\section{B. Cognitive distortion}

The term 'cognitive distortion' seems to have been adopted from the cognitive therapy literature on depression. In this field, the term was originally used to describe 'Idiosyncratic thought content indicative of distorted or unrealistic conceptualizations' (Maruna \& Mann, 2006). Cognitive distortion was used to describe seemingly unusual beliefs about the self, such as self-blame, self-criticism, helplessness and hopelessness providing an explicit account as to why such beliefs can be distorted and unusual within our cultural context (Salhah Abdullah, Amla Salleh, Zuria Mahmud, Jamil Ahmad, \& Saedah Abd Ghani, 2011). Cognitive distortion also refers to unusual beliefs about self; such having self-blame, self-criticism, helplessness and hopelessness (Zainah Ahmad Zamani, Rohany Nasir, Asmawati Desa, Rozainee Khairudin, \& Fatimah Yusooff, 2014)

Kwang and Swann Jr (2010) said that the tendency to engage in the cognitive restructuring of social information and in self-serving biases (to protect positive image of one self or to verify one's world views and already established selfschemas) is prevalent among humans. Various kinds of cognitive errors are often considered important factors in the development of maladaptive emotional and behavioral reactions. According to empirical literature, the negative framing of one's experiences related to cognitive distortions can significantly impact a person's self-view, emotions and patterns of interpersonal interactions (Besta et al., 2014)

As mention before, cognitive distortions include selfcriticism, self-blaming, helplessness, hopelessness, and preoccupation of danger. These characteristics were developed by Briere (2000) in his study of the cognitive distortion scale. The descriptions are mention below:

Self-criticism (SC) measures the tendency to criticize or devalue oneself, both internally and to others. Although this construct is usually labeled "low esteem," it is referred to in the cognitive distortion scale (CDS) as Self-criticism in order to more directly capture the behavioral aspects of this thinking pattern. Individuals with clinical elevations on this scale are likely to view themselves in an especially negative light and to report repetitive negative thoughts about their intrinsic badness or unacceptability. In some individuals, this selfperception style may manifest as frank self-hatred or selfdisgust, suggesting considerable anger that is at least partially directed inward. Individuals with high SC scores often have experienced, at minimum, some level of excessive criticism or devaluation as children, although this is not inevitably so. In addition, some individuals with histories of childhood physical or sexual abuse may have elevated scores on SC. Alternatively, or in addition, individuals who have committed acts in adulthood that are perceived as especially abhorrent or deviant may produce high SC scores.

Self-blame (SB) evaluates the extent to which the respondent blames himself or herself for negative, unwanted events that have transpired in his or her life. Respondents with elevated SB scores tend to make negative internal attributions regarding the meaning of adverse life experiences, believing that they are personally responsible for negative outcomes. Often, such attributions will not appear to be especially reality-based, such as blaming oneself for an assault or victimization experience that was out of one's control. In other instances, SB will be elevated because the individual correctly perceives some responsibility for an act that occurred against him/her, but nevertheless may be elevated beyond the actual level of responsibility present. Elevated SB also may be found in depressed individuals who generally over-attribute negative responsibility as part of their cognitive-emotional state.

Helplessness (HLP) measures the perception of being unable to control or influence important, typically negative aspects of one's life. Individuals with high HLP scores may be especially likely to assume that their efforts to change an unwanted or problematic situation will be unsuccessful, sometimes leading to passivity or avoidance in the face of challenge or danger. The assumed inability to influence negative events in one's life is often projected into the future, hence the high correlation between the Helplessness and Hopelessness scales of the CDS. This combination may be especially relevant to individuals who are currently being victimized or maltreated in a sexual/romantic or occupational relationship, wherein high HLP (and HOP) may result in a perceived inability to change or leave such relationships.

Hopelessness (HOP) measures the extent to which the respondent believes that the future is bleak and that he or she is destined to suffer or fail. Those with elevated scores on the HOP scale are often characterized as pessimistic, and may be especially likely to avoid (or fail to persevere in) activities that require an expectation of a potentially positive future outcome. High HOP scores are usually suggestive of some level of dysthymia or depression. Hopelessness is correlated with suicidality in the normative and validity samples of the CDS and in suicide literature. This may be due to the tendency for high HOP responders to assume that their current pain or distress is likely to continue indefinitely, thereby motivating escape at any cost.

Preoccupation with Danger (PWD) evaluates the respondent's tendency to view the world as a dangerous place, especially in the interpersonal domain. Although not inevitably so, the normative and validity studies indicate that those with high levels of PWD often have experienced interpersonal victimization in childhood or later in life, and may suffer some symptoms of posttraumatic stress. Anxiety is also a symptomatic correlation to high PWD. Individuals with elevated PWD scores typically are hypervigilant to danger and may assume that objectively benign circumstances or events contain risk of emotional or physical injury. This overevaluation of danger may produce a tendency to avoid interpersonal challenges or perceived vulnerability

\section{Religious coping}

Among some groups, particularly the elderly, minorities, and individuals facing life-threatening crises, religion is cited more frequently than any other resource for coping (Pargament, Koenig, \& Perez, 2000). Pargament identified the positive impacts of different kinds of religious coping which referred to the religious aspect and told that religion can be a part of the central structure of each coping process. He 
believes that religion is able to provide suitable resources for individuals to cope with threatening situations.

Pargament, Koenig, and Perez (1998) identified two patterns of religious coping including positive and negative with potential implications for health. The pattern of positive religious coping methods is an expression of a sense of spirituality, a secure relationship with God, a belief that there is meaning to be found in life, and a sense of spiritual connectedness with others (Aflakeiser \& Coleman, 2011), which include prayers (Tarakeshwar, Vanderwerker, Paulk, Pearce, Kasl, \& Prigerson, 2006). According to them, several forms of religious coping are part of this pattern: benevolent religious reappraisal, collaborative religious coping, seeking spiritual support, spiritual connection, religious purification, seeking help from clergy or members, religious helping, and religious forgiveness

In Islam, religious coping could be related to five medicines of the heart. The first is reading the Qur'an with reflection, then fasting, regular night prayers, dzikir all night long, and togetherness with righteous people (Ibnu Al-Jauzi, 1985). Hasan bin 'Uluwiyah said: I heard Yahya bin Muadz said: Medicine of heart are five items; read Qur'an with understanding of the meaning; fasting; night praying; remembering Allah all the night; and togetherness with righteous people (Ibnu Al-Jauzi, 1985).

\section{MethodologY}

This study was used survey research, which provides accurate and efficient means for describing people's characteristics (e.g., demographic variables) and their thoughts, opinions, and feelings. In addition, predictive relationships can be identified by assessing the covariation (correlation) among naturally occurring variables (Shaughnessy, Zechmesiter, \& Zechmeister, 2015)

The population of this study is single mothers from Yogyakarta, Indonesia. The data from Badan Pusat Statistik (BPS) 2013 notes the percentage of women aged ten and above, whereby $2.17 \%$ are divorced and $11.47 \%$ are widows (Badan Pusat Statistik). The sample of this study consists of 100 Muslim single mothers in Yogyakarta, Indonesia, in which the majority have come from communities of single mothers.

\section{A. Instruments}

The Coping Strategy Inventory (CSI) comprises of 40 items originally designed by Cano Garcia in 2007. It was adapted and translated from the Spanish Version of Coping Strategies (Salhah Abdullah, Sapora Sipon, Dini Farhana Baharudin, \& Rezki Perdani Sawai, 2011). Respondents are required to answer 40 items to measure the way of coping based on three strategies; focusing on managing emotion, focusing on adaptive and maladaptive; and focusing on emotion. A five-point Likert-scale from 1 to 5 was used to indicate self-rating for each item. Eight primary factors (problem solving, cognitive restructuring, emotional expression, social support, problem avoidance, wishful thinking, self-criticism, and social withdrawal) identified as a dimension of coping (Salhah Abdullah et al., 2011)

The Religious Coping Inventory is built up from adaption of Brief Religious Coping (BRCOPE) captured from Pargament (1997), which was then adopted and revised in
Malay (Salhah Abdullah, Sapora Sipon, Husni Mohd Radzi, \& Zulkepli Abd Ghani, 2015) and the researcher also employed two factors (religious forgiving and ritual) into this instrument. The factors are doubt about God's love and power, self-reflection and wishful thinking, coping to achieve a life transformation, religious forgiving, and rituals.

Briere's Cognitive Distortion Scale (CDS) is a 40-item instrument that measures five types of cognitive symptoms of distortion, i.e., self-criticism, self-blame, helplessness, hopelessness and preoccupation with danger, which are found among those who experienced interpersonal victimization. All factors have good internal consistency and convergent validity with other cognitive distortion measures in various clinical and nonclinical samples (Salhah Abdullah et al., 2011). The CDS items are measured on a 5-point Likert Scale $(1=$ Never to $5=$ most of the time), with the possible range of a total score of $40-200$.

The determining distribution factor of all instruments means that the raw score of each subscale of the instruments represent the majority factors that influence respondents. This means that the highest score of each subscale is the factor that respondents usually apply. The researcher could determine how many respondents used each scale from the three instruments.

\section{RESULTS AND DISCUSSION}

\section{A. Coping Strategy}

The highest score of coping strategy in this study was cognitive restructuring among single mothers, which is the cognitive strategies that modify the meaning of the stressful situation (Garcia et al., 2007). The research by Compas and Williams (1990) found that specifically, single mothers reported using more coping strategies related to accepting responsibility for problems and positively reappraising stressful situations than married mothers. These coping strategies may reflect the realities of single-parent life. Without a marital partner to share the responsibilities of the stresses of daily life, single mothers may be forced to accept a greater burden of responsibility. However, the past sample of single mothers in Compas and Williams's study seemed to have balanced this realistic approach to coping by attempting to focus on the positive aspects of the stressful situations which they confronted (Compas \& Williams, 1990). That means that by focusing to the positive factors, single mothers modify the meaning of the stressful situation, and the findings support the previous study as mention above.

In addition, the secondary scale of coping strategy used by single mothers in this study focuses on adaptive and maladaptive. The secondary scale of this study is consist of three, which were focusing on managing emotion, focusing on adaptive and maladaptive, and focusing on emotion. The scale of focusing on adaptive and maladaptive consists of problem solving, problem avoidance, and self-criticism which is similar with problem-focused coping. Some past research found that single mothers used problem-focused coping. Research by Pitasari and Cahyono (2014) with two respondents found the setting and financial planning that was built over the years to be a mess. This is in accordance with respondents one and two who experienced a change in economic terms after the death of the husband. Although they still have money savings, both respondents doubt whether 
they can send their children as high as possible, because the cost of education is not small. Respondent one started saving money for the future of her children so that her children will not be lacking and can take as much education as possible. Respondent two used to work but because of the condition of the children who need the presence of the mother, she decided to get out of work and open a business at home (Pitasari \& Cahyono, 2014).

The findings of Pitasari and Cahyono's (2014) study is supported by this study in that single mothers usually use problem-focused coping as a coping strategy similar to focusing on the adaptive and maladaptive scale.

Table 1. Statistical results of coping strategy.

\begin{tabular}{ccc}
\hline Factors & Frequency & $\begin{array}{c}\text { Percentage } \\
(\%)\end{array}$ \\
\hline Problem solving & 18 & 14.75 \\
Self-criticism & 3 & 2.46 \\
Emotional & 1 & 0.82 \\
expression & 21 & 17.21 \\
Wishful thinking & 5 & 4.1 \\
Social support & 67 & 54.92 \\
Cognitive & & \\
restructuring & 7 & 5.74 \\
Problem & 0 & 0 \\
avoidance & 122 & 100 \\
Social withdrawal & & \\
Total & &
\end{tabular}

Source: Primary data.

\section{B. Religious Coping}

The highest score of religious coping found in this study is religious forgiving. Religious forgiving is looking for help in shifting from anger, hurt, and fear associated with an offense to peace (Pargament et al., 2000). As in the study of Ariati and Wahyuningsih (2008) the respondent gets closer to God by praying to have more patience and an easy way to face problems. This is the respondent's way of religious focused coping (Ariati \& Wahyuningsih, 2008). This supports the results of previous studies that single mothers seek for help from God to shift their anger and hurt by being patient and find an easy way to face their problem.

Religious forgiving becomes important as a part of religious coping because religious forgiving could make an individual feel more calm and at peace. As in surah Al-Imran: 159 mentioned below:

"So by mercy from Allah, [O Muhammad], you were lenient with them. And if you had been rude [in speech] and harsh in heart, they would have disbanded from about you. So pardon them and ask forgiveness for them and consult them in the matter. And when you have decided, then rely upon Allah. Indeed, Allah loves those who rely [upon Him]". (Al-Qur'an. Ali Imran 3:159)

"If [instead] you show [some] good or conceal it or pardon an offense - indeed, Allah is ever Pardoning and Competent". (Al-Qur'an. An-Nisa' 4:149)
"That [is so]. And whoever responds [to injustice] with the equivalent of that with which he was harmed and then is tyrannized - Allah will surely aid him. Indeed, Allah is Pardoning and Forgiving". (Al-Qur'an. Al-Hajj 22:60).

Table 2. Statistical results of religious coping strategy.

\begin{tabular}{|c|c|c|}
\hline Factors & Frequency & $\begin{array}{c}\text { Percentage } \\
(\%)\end{array}$ \\
\hline Doubt about & & \\
\hline $\begin{array}{l}\text { God's love and } \\
\text { power }\end{array}$ & 0 & 0 \\
\hline $\begin{array}{l}\text { Self-reflection and } \\
\text { wishful thinking }\end{array}$ & 0 & 0 \\
\hline $\begin{array}{c}\text { Coping to achieve } \\
\text { a life } \\
\text { transformation }\end{array}$ & 7 & 5.47 \\
\hline $\begin{array}{l}\text { Religious } \\
\text { forgiving }\end{array}$ & 70 & 54.69 \\
\hline Rituals & 51 & 39.48 \\
\hline Total & 128 & 100 \\
\hline
\end{tabular}

Source: Primary data.

\section{Cognitive Distortion}

As the results found in this study, the factors of cognitive distortion in the majority of single mothers was preoccupation of danger. The preoccupation of danger is similar with negative assumption that has been studied by Ariati and Wahyuningsih (2008). The study of Ariati and Wahyuningsih (2008) which found that single mothers living in society also have pressures regarding negative assumptions. A single mother who lives with her children is assumed to be lonely, and her behaviors are being watched. Single mothers also often become a subject of gossip when they have activities with men. An example is the story of $Y$ that people gossiped about her as a woman that take over another's husband just because the man usually buy some goods in her shop (Ariati $\&$ Wahyuningsih, 2008). This is supported in the results of this study, in which the single mothers' cognitive distortion is preoccupation of danger; they feel unsafe when they are around the society. They feel danger and awkward because of gossip. Even so, majority of the respondents have less experience in cognitive distortion.

The preoccupation of danger and negative assumption that describe above is related to the definition of preoccupation of danger by Briere (2000), that preoccupation of danger evaluates the respondent's tendency to view the world as a dangerous place, especially in the interpersonal domain.

Table 3. Statistical results of religious coping strategy.

\begin{tabular}{ccc}
\hline Factors & Frequency & $\begin{array}{c}\text { Percentage } \\
(\%)\end{array}$ \\
\hline Self-criticism & 13 & 10.32 \\
Self-blaming & 18 & 14.29 \\
Helplessness & 38 & 30.16 \\
Hopelessness & 11 & 8.73 \\
Preoccupation of & 46 & 36.5 \\
danger & 126 & 100 \\
Total & &
\end{tabular}

Source: Primary data.

\section{CONCLUSION}

In summary, the researcher has found that the highest score of coping strategy's factor is cognitive restructuring. The highest score of cognitive distortion's factor is 
preoccupation of danger, and the highest score of religious coping's factor is religious forgiving. Furthermore, in examining correlation using Pearson Correlation, there is a significant relationship between coping strategy and cognitive distortion, but there is no significant relationship between religious coping and cognitive distortion.

\section{REFERENCES}

[1] Aflakeiser, A., \& Coleman, P. G. 2011. "Initial Development of the Iranian Religious Coping Scale". Journal of Muslim Mental Health. Vol.7. p 44-61.

[2] Ariati, L., \& Wahyuningsih, H. 2008. Coping Behavior pada Ibu Rumah Tangga yang Memutuskan Tidak Menikah Lagi Karena Suaminya Meninggal. (Naskah Publikasi). Yogyakarta: Universitas Islam Indonesia.

[3] Badan Pusat Statistik. (n.d.). "Persentase Penduduk Berumur 10 Tahun Keatas Menurut Provinsi, Jenis Kelamin, dan Status Perkawinan". Badan Pusat Statistik (www.bps.go.id). accessed: 8 October 2015

[4] Besta, T., Barczak, A., Lewandowska-Walter, A., \& Dozois, D. J. 2014. "Polish Version of the Cognitive Distortion Scale (CDS): Preliminary Validation and Personality Correlates". Current Issues in Personality Psychology. Vol. 2. p 177-183.

[5] Briere, J. 2000. "Cognitive Distortion Scales John Briere Ph.D". John Briere Ph.D (www.johnbriere.com). accessed: 8 October 2015

[6] Compas, B. E., \& Williams, R. A. 1990. "Stress, Coping, and Adjustment in Mothers and Young Adolescents in Single- and TwoParent Families". American Journal of Community Psychology. Vol. 18. p 525-545.

[7] DeFrain, J. 1999. "Strong Families". Family Matters. Vol. 53. p 6-13.

[8] Garcia, F. J., Franco, L. R., \& Marinez, J. G. 2007. "Spanish Version of Coping Strategies Inventory". Actas Esp Psiquiatr. Vol. 35. p 29-39.

[9] Ibnu Al-Jauzi, J. A. 1985. Kitab Shifat Al-Shafwah Volume 4". Beirut, Lebanon: Darul Ma'rifah.

[10] Lazarus, R. S. 1993. "Coping Theory and Research: Past, Present, and Future". Psychosomatic Medicine. Vol. 55. p 234-247.
[11] Lazarus, R. S., \& Folkman, S. 1984. Stress, Appraisal, and Coping. New York: Springer Publisher Company.

[12] Maruna, S., \& Mann, R. E. 2006. "A Fundamental Contribution Error? Rethinking Cognitive Distortion". Legal and Criminological Psychology. Vol. 11. p 155-177.

[13] Naidoo, P. 1998. "The Experience of Divorced Mother as SingleParents". Psychology in Society. Vol. 23. p 17-34.

[14] Pargament, K. I., Koenig, H. G., \& Perez, L. M. 2000. "The Many Method of Religious Coping: Development and Initial Validation of RCOPE". Journal of Clinical Psychology. Vol. 56. p 519-543.

[15] Pitasari, A. T., \& Cahyono, R. 2014. "Coping pada Ibu yang Berperan Sebagai Orangtua Tunggal Pasca Kematian Suami". Jurnal Psikologi Pendidikan dan Perkembangan. Vol. 3. p 37-41.

[16] Salhah Abdullah, Amla Salleh, Zuria Mahmud, Jamil Ahmad, \& Saedah Abd Ghani. 2011. "Cognitive Distortion, Depression, and Self Esteem among Adolescents Rape Victims". World Applied Sciences Journal (Learning Innovation and Intervention for Divers Learners. Vol. 14. p 67-73.

[17] Salhah Abdullah, Sapora Sipon, Dini Farhana Baharudin, \& Rezki Perdani Sawai. 2011. "Strategi Daya Tindak Versi Bahasa Melayu". Perkama International Counseling Convention 2011. Nilai: PERKAMA.

[18] Salhah Abdullah, Sapora Sipon, Husni Mohd Radzi, \& Zulkepli Abd Ghani. 2015. "Stress and Religious Coping among Flood Victims in Malaysia". The 2015 WEI International Academic Conference Proceedings (pp. 79-87). Vienna: The West East Institue.

[19] Shaughnessy, J. J., Zechmesiter, E. B., \& Zechmeister, J. S. 2015. Research Method in Psychology, Tenth Edition. New York: McGraw Hill Education.

[20] Tarakeshwar, N., Vanderwerker, L. C., Paulk, E., Pearce, M. J., Kasl, S. V., \& Prigerson, H. G. 2006. "Religious Coping is Associated with the Quality of Life of Patients with Advanced Cancer". J Palliat Med.Vol. 9. (3): p 646-657.

[21] Zainah Ahmad Zamani, Rohany Nasir, Asmawati Desa, Rozainee Khairudin, \& Fatimah Yusooff. 2014. "Family Functioning, Cognitive Distortion and Resilience among Clients under Treatment in Drug Rehabilitation Centres in Malaysia". Procedia-Social and Behavioral Sciences. Vol. 140. p 150-154. 